\title{
A review study: Development of microbial enhancing oil recovery technology
}

\author{
Wenfeng Song ${ }^{1 a^{*}}$, Desheng $\mathrm{Ma}^{1 \mathrm{~b}}$, Kangyun $\mathrm{Wu}^{1 \mathrm{c}}$, Xiaofang $\mathrm{Wei}^{1 \mathrm{~d}}$, Ying $\mathrm{Xu}^{1 \mathrm{e}}$ \\ ${ }^{1}$ State Key Laboratory of Enhanced Oil Recovery, Research Institute of Petroleum Exploration and \\ Development, CNPC, Beijing 100083, China \\ asongwf@petrochina.com.cn, ${ }^{b}$ mads6@petrochina.com.cn, cwukangyun@petrochina.com.cn, \\ dxiaofangwei@petrochina.com.cn, exuying2014@petrochina.com.cn. \\ ${ }^{*}$ Corresponding author
}

Keywords: MEOR, exogenous, indigenous, pilot application, field test, microbes

\begin{abstract}
There are over 2 trillion barrels of conventional oil still remain reservoirs worldwide after conventional recovery methods have been exhausted. Based on these many techniques that involved in tertiary oil recovery were developed. However, most of these technologies restrict the further development of oilfields because of their economic limitations. Microbial enhanced oil recovery (MEOR) technique has been proposed for many years as a cheap and effective alternative to enhance oil recovery as its different processes generally do not depend on oil prices. MEOR pilot tests have been applied in many oilfields around the worlds. However, this method did not receive a great attention in the petroleum industry because of its technical bottlenecks. This paper is mainly focused on discussing the basic concept, mechanism, advantages, problems and further trends of MEOR.
\end{abstract}

\section{Introduction}

MEOR is one of tertiary oil recovery techniques that belongs a pioneering application of biological engineering technology in oilfield development (1). MEOR is the technique that mainly used microorganisms (indigenous and/or exogenous) and their microbial components (e.g. metabolites, enzymes, bio-gases and even biochemical pathways, etc.) to interact with oil compounds inside of the porous medium, thereby improving oil recovery $(2,3)$. Microbial candidates are generally small sized molecules $(0.5-5 \mu \mathrm{m})$, which facilitate their migration through porous medium (4). Basically, the cellular size of microbes should be less than $20 \%$ of pore throat volume of the porous medium $(5,6)$. Previous study reported that swept volume of injected cell liquid could reach to $60,000 \mathrm{~m}^{2}$ when target reservoir permeability greater than 0.6 Darcy (D) (7). Moreover, some microbes could survive and maintain their normal metabolic process in a strict conditions (2). For examples, Bacillus and Clostridium that usually used in MEOR might live in high temperature and high pressure reservoir conditions during the formation of spores $(8,9)$.

MEOR could be roughly divided into two groups, the indigenous and exogenous MEOR methods. In the early stage, microbes used in MEOR were usually isolated out of oil reservoirs. Those EOR functional microbes were cultured on the ground, and injected underground subsequently. Exogenous microbes generally exhibited good EOR function, whereas they showed low adaptability and affinity to the target reservoir. Therefore, indigenous MEOR technique has been developed in the recent years. In indigenous MEOR method, microorganisms inside of the target reservoir are directly activated by injection of nutrients. Microbial candidates do not need to be cultured on the ground. Those functional cells have a higher adaptability and affinity to reservoir than that of exogenous bacteria.

\section{Development history of MEOR}

The use of microorganisms to displace oil from porous medium was firstly introduced by American scientist Beckman in 1926 (10). From 1947 to 1955, Zobell and his group did a series 
researches which contributed to a development of MEOR (11). Many microbes were studied in their research, including anaerobic bacteria, alkane degrading bacteria and sulphate-reducing bacteria (SRB). However, the development of MEOR fell into stagnation in 1970's because of the global economic crisis (12). Oil price subsequently nose-dived in worldwide from 1980's to 1990's. Based on this, more and more researches were re-focused on MEOR because of its low cost and generally did not depend on oil price.

In 1980's many filed applications were conducted in United States (13). In the past 20 years, there were at least 47 MEOR researches have been carried out (14). MEOR was also well-developed fast in Russia by using indigenous microbes. The technique has been entered into industrial stage in Russia at present. Moreover, the MEOR has been developed extensively in England in 1990's, including studies of reservoir simulator and effectiveness prediction (15). The technique started relatively late in China. It was firstly introduced from United States and Canada in 1960's. Only two single wells have been applied at the end of 1980's. At the late1990's, MEOR research has been developed from a single well to blocks in several oilfields of China.

Nowadays, MEOR techniques improved very fast based on a rapid development of molecular cloning technology. MEOR has already become one of important techniques in tertiary oil recovery after thermal drive, chemical and polymer flooding.

\section{Basic principle of MEOR}

MEOR principle is more complex than other tertiary EOR techniques, because of different types of functional microorganisms (Table 1). Their principles could be roughly divided into two main classes, changing compositions of oil compounds and improving oil flooding environments (16, 17).

1. Changes in oil compositions:

a. Microorganisms could uptake high molecular weight hydrocarbons (alkanes, aromatics), which are then degraded into small molecules through cellular normal metabolic processes. Oil fluidity might be increased by reducing oil viscosity, thereby improving EOR efficiency.

b. Functional enzymes might be also released during the growth of microbes. Some of these enzymes exhibit a high affinity to oil compounds and play a key role in oil bio-degradation.

2. Improvement of oil flooding environments:

a. Metabolites produced by microbes contains oil flooding functional molecules. For examples, bio-surfactants could change the wettability between oil and stone, reduce both of surface tension and interfacial tension. Some of metabolites are amphiphilic molecules which contain both hydrophilic and lipophilic groups. Those molecules could bind both water and oil molecules resulting in oil/water emulsification, thereby increasing oil fluidity.

b. Organic acids can dissolute carbonate and/or inorganic mineral scale of rock, resulting in improving the formation of permeability.

c. Alcohols and ketones released by microbial cells might dissolve oils thereby increasing oil fluidity.

d. Bio-gas (such as $\mathrm{CO}_{2}, \mathrm{CH}_{4}$, and $\mathrm{H}_{2} \mathrm{~S}$ ) can replenish formation pressure, and dissolved into oil to improve oil fluidity.

e. Bio-polymers could increase viscosity of injected water, thereby improving mobility ratio.

\section{MEOR pilot application}

The key point of MEOR is successfully direct (injection of exogenous microbial cultures) or indirect (injection of nutrients) activation of functional microbes under the target oil reservoirs. In the past 40 years, MEOR field tests have been conducted in more than 20 countries around the world. Most of those pilot applications exhibited a significantly increase in EOR efficiency (Table 2). 
Table 1. Functional cellular molecules and their MEOR principles of different microorganisms (18).

\begin{tabular}{|c|c|c|}
\hline Functional molecules & Microorganisms & MEOR principles \\
\hline Biomass & $\begin{array}{l}\text { Bacillus licheniformis, } \\
\text { Leuconostoc mesenteroides, } \\
\text { Xanthomonas campestris }\end{array}$ & $\begin{array}{l}\text { Reduce oil viscosity, } \\
\text { bio-degradation, changing } \\
\text { wettability, }\end{array}$ \\
\hline Bio-surfactants & $\begin{array}{c}\text { Acinetobacter calcoaceticus, } \\
\text { Arthrobacter Paraffineus, Bacillus } \\
\text { sp., Pseudomonas sp., Clostridium } \\
\text { sp. }\end{array}$ & $\begin{array}{l}\text { Emulsification, reduce } \\
\text { interfacial tension, reduce oil } \\
\text { viscosity }\end{array}$ \\
\hline Bio-polymers & $\begin{array}{c}\text { Bacillus polymyxa, Brevibacterium } \\
\text { viscogenes, Leuconostoc } \\
\text { mesenteroides, Enterobacter sp. }\end{array}$ & Improve water/oil mobility ratio \\
\hline Bio-solvents & $\begin{array}{c}\text { Clostridium sp., Zymomonas } \\
\text { mobilis, }\end{array}$ & $\begin{array}{l}\text { Emulsification, reduce oil } \\
\text { viscosity }\end{array}$ \\
\hline Organic acids & $\begin{array}{c}\text { Clostridium sp., Enterobacter } \\
\text { aerogenes }\end{array}$ & $\begin{array}{c}\text { Increase rock permeability, } \\
\text { emulsification }\end{array}$ \\
\hline Bio-gases & $\begin{array}{c}\text { Clostridium sp., Enterobacter } \\
\text { aerogenes, Methanobacterium sp. }\end{array}$ & $\begin{array}{l}\text { Replenish formation pressure, } \\
\text { reduce interfacial tension, } \\
\text { reduce oil viscosity, increase } \\
\text { rock permeability }\end{array}$ \\
\hline
\end{tabular}

Table 2. MEOR pilot application and the use of functional microbes in the past 40 years

\begin{tabular}{|c|c|c|c|}
\hline Countries & Functional microbes & EOR efficiency & References \\
\hline USA & $\begin{array}{c}\text { Bacillus, Clostridium, Pseudomonas, } \\
\text { alkane degrading bacteria, } \\
\text { Microtatobiotes and indigenous micro } \\
\text { flora, etc. }\end{array}$ & + (19-21) \\
\hline Russia & $\begin{array}{c}\text { Clostridium tyrobutiricum, indigenous } \\
\text { micro flora, sewage bacteria, and mixed } \\
\text { culture, etc. }\end{array}$ & + & $(\underline{22})$ \\
\hline China & $\begin{array}{c}\text { Bacillus, Pseudomonas, Fusobacterium, } \\
\text { bacteroidete, bio-polymers and } \\
\text { bio-surfactants, etc. }\end{array}$ & + & $(\underline{23})$ \\
\hline Australia & Microtatobiotes & + & $(\underline{24})$ \\
\hline Bulgaria & Hydrocarbon oxidizing bacteria & $(\underline{5,} \underline{26})$ \\
\hline Canada & Leuconostoc mesenteroides & $(\underline{27})$ \\
\hline Czechoslovakia & Pseudomonas and SRB & + & $(\underline{29})$ \\
\hline Great Britain & Acid-producing bacteria, & + & $(\underline{30})$ \\
\hline Germany & $\begin{array}{c}\text { Thermophilic Bacillus, Clostridium and } \\
\text { indigenous micro flora, etc. }\end{array}$ & $(\underline{31})$ \\
\hline Hungary & Sewage mixed culture & + & $(\underline{32}, \underline{33})$ \\
\hline Norway & Nitrate reducing bacteria & + & $(\underline{3})$ \\
\hline Poland & Mixed culture & + & + \\
\hline Romania & $\begin{array}{c}\text { Bacillus, Clostridium, Pseudomonas and } \\
\text { mixed culture, etc. }\end{array}$ & + & + \\
\hline Holland & Betacoccus dextranicus & + & + \\
\hline
\end{tabular}

\section{Advantages of MEOR}

In contrast to other tertiary techniques, MEOR has its own distinctive advantages(34). Firstly, MEOR is economic efficiency, and its cost do not depend on oil prices. Secondly, microbes are rich 
in diversity under target reservoirs. The activated microbes might produce multi-functions during oil displacement. Thirdly, microbes could voluntarily migrate inside of porous medium. Fourthly, indigenous microbes showed a highly affinity to target reservoir conditions (temperature, permeability and pressure). Finally, MEOR is absolutely environmental friendly. Microbes used for oil displacement are generally existed in a natural world. Functional cells might be dead after oil displacement application (short of nutrients), thereby preventing secondary pollutions.

\section{Bottlenecks of MEOR technique}

However, MEOR still have some drawbacks which might limit its further industrial applications. The main technical bottlenecks are concluded below $(35,36)$ :

1. Microbial factors: Firstly, exogenous bacteria exhibit a lower adaptability to reservoirs. Introduced of exogenous microorganisms might result in changes of distribution, diversity and communication of microbes in the target reservoir. Those changes would further lead an imbalance in symbiotic system, which is then inhibited the growth of the functional cells. Secondly, indigenous microbes show a highly affinity to the target oil reservoirs. However, enzymatic activity of microbes might be inhibited in a strict condition (e.g. $>80^{\circ} \mathrm{C}, 4>\mathrm{pH}>9.5$, high salinity, etc.), even if they are still survived. They would not function on oil displacement in a natural reservoir environment. Thirdly, reservoir is known as a great reactor. Once the nutrients are injected, they would be highly diluted. Therefore, active efficiency of functional cells could not be that high as we expected. Moreover, culture medium usually contains common nutrients (e.g. carbohydrates, and inorganic ions. etc.) which could be utilized by most of cells but not only the functional microbes. Thus, the well-growth cell and functional cell might not be matched.

2. Metabolites: Some of cellular metabolites play a role in EOR (e.g. bio-surfactants, bio-polymers and bio-gas, etc.). However, the productivity of natural cells are generally low. The limited yield of metabolites may not lead to a significantly positive effects on EOR. Moreover, the aggregation of metabolites in the environment may cause a toxic effect to their parent cells, thereby subsequently inhibiting cellular enzyme activity.

3. MEOR mechanisms: MEOR mechanism still need to be deeply understand, including functional gene expression when exposed to target oil compounds, enzyme construction that encoded by the functional genes, role of functional enzymes in degradation of oil compounds, etc. Furthermore, MEOR mechanisms are generally complicated, because of that different microbial candidates relate to different mechanisms.

4. Field tests: MEOR applied blocks are often assessed in the production tail. The situation underground is very complicated. There is lack of knowledge that exact interaction between microbes and oils under the target reservoirs.

\section{Future trends}

MEOR has been developed for near a century that is unmatched by others based on their economic efficiency and environment protection. It gradually becomes an important technique of tertiary oil recovery technologies, especially for exploitation of high water-cut and heavy oil reservoirs. To overcome its limitations thereby facilitating the further industrial applications, the development of MEOR might be focused on the following aspects in the future:

1. Construction of functional microbial library: Diversities and distributions of indigenous microorganisms under target oil reservoirs should be screened and analyzed by using molecular cloning technology. The microbial candidates could be then isolated and classified based on their different oil-displacement functions.

2. Deeply study on MEOR mechanism: Mechanism study should focus one or several functional microorganisms. Those cells could be selected from functional microbial library that may exhibit different oil-displacement functions. Their MEOR mechanisms are subsequently studied, including structural gene expression, functional enzyme formation and the key bio-chemical 
pathways, etc.

3. Introduction of genetically modified cells: Genetic enhancement of functional genes might improve the yields of functional metabolites (bio-surfactants, bio-gases and key enzymes, etc.) per unit time, thereby accelerating EOR effective period. Transformation of exogenous genes (thermo-genes isolated from thermophilic bacteria) into indigenous functional cells could be used to resist the strict conditions, resulting in an improvement in adaptability and universality of functional cells under the target reservoir conditions.

\section{Conclusions}

MEOR has been developed for several decades. It is unmatched by other tertiary EOR methods based on its economic efficiency and good ecological characters. MEOR pilot tests have been applied in oilfields of many countries around the world, and exhibited significant results in EOR efficiency. MEOR could improve EOR by either changing oil property and/or improving oil-displacement environment. However, there are still some bottlenecks which might limit its industrialization, need to be overcome in the future research.

\section{References:}

[1]. Dou, Q., Chen, J., Wang, J., and Zhang, D. (2004) Advances in researches and outlook for microbial enhanced oil recovery, Natural Gas Industry 15, 559-563.

[2]. Al-Sulaimani, H., Joshi, S., Al-Wahaibi, Y., Al-Bahry, S., Elshafie, A., and Al-Bemani, A. (2011) Microbial Biotechnology for enhancing oil recovery: Current developments and future prospects, Biotechnology, Bioinformatics and Bioengineering 1, 147-158.

[3]. Lazar, I., Petrisor, I. G., and Yen, T. F. (2007) Microbial enhanced oil recovery (MEOR), Petroleum Science and Technology 25, 1353-1366.

[4]. Sarafzadeh, P., Hezave, A. Z., Mohammadi, S., Niazi, A., and Ayatollahi, A. (2014) Modification of rock/fluid and fluid/fluid interfaces during MEOR processes, using two biosurfactant producing strains of Bacillus stearothermophilus SUCPM\#14 and Enterobacter cloacae: A mechanistic study., Colloids and Surfaces B: Biointerfaces 117.

[5]. Jack, T. R., and Steheier, G. L. (1988) Applications of Microorganisms to Petroleum Technology, Springfield, Virginia.

[6]. Brown, L. R. (2010) Microbial enhanced oil recovery, Current Opinion in Microbiology 13, 316-320.

[7]. Jang, L. K., Chang, P. W., and Findley, J. E. (1983) Selection of bacteria with favorable transport properties through porous rock for the application of microbial enhanced oil recovery, Applied Enviromental Microbiology 46, 1066-1072.

[8]. Zekri, A. Y., Almehaideb, R. A., and Chaalal, O. (1999) Project of increasing oil recovery from UAE reservoirs using bacteria flooding, SPE Houston.

[9]. Maudgalya, S., Knapp, R. M., and Mclnemey, M. J. (2007) Microbially enhanced oil recovery technologies: a review of the past, present and further, SPE, Oklahoma.

[10]. Zobell, C. (1946) Action of microorganisms on hydrocarbons, Bacteriol Rev 10, 1-49.

[11]. Zobell, C. (1947) Bacterial release of oil from sedimentary materials, Oil and Gas Journal 46, 62-65.

[12]. Behlulgil, K., and Mehmetoglu, M. T. (2003) Mathematical modeling of the soaking period in a microbial enhanced oil recovery application, Energy Sources 25, 871-877.

[13]. Liu, L. (2009) Advances in researching the techniques of microbial enhanced oil recovery and their application prospects, Sino-Global Energy 14, 41-45. 
[14]. van Hamme, J. D., Singh, A., and Ward, O. P. (2003) Recent advances in petroleum microbiology, Microbiology and Molecular Biology Reviews 67, 503-509.

[15]. Thormas, S. (2007) Enhanced oil recovery - An overview, Oil \& Gas Science \& Technology 63, 9-19.

[16]. Chang, Y. (2006) The principle and applications of indigenous microbial enhanced oil recovery technology, Science \& Technology Information 13, 109.

[17]. Lai, F. P., Cen, F., Huang, Z. W., and Xu, J. (2006) Summary of microbial enhanced oil recovery technology development, Resources \& Industries 8, 60-62.

[18]. McInerney, M. J., and Sublette, K. L. (2002) Oilfield Microbiology 2 nd ed., ASM, Washington, D.C.

[19]. Coates, J. D., Chisholm, R. M., Mclnemey, M. J., Menzie, D. E., and Bhupathiraju, V. K. (1993) Microbially enhanced oil recovery field pilot, Payne County, Oklahoma, Developments in Petroleum Science 39, 197-205.

[20]. Jenneman, G. E., Clark, J. B., and Moffitt, P. D. (1993) A nutrient control process for microbially enhanced oil recovery applications, Developments in Petroleum Science, 1993 39, 319-333.

[21]. Nelson, L., and Schneider, D. R. (1993) Six years of paraffin control and enhanced oil recovery with the microbial product, Para-Bac, Developments in Petroleum Science 39, 355-362.

[22]. Osipov, G. A., Nazina, T. N., and Lvanova, A. E. (1995) Study of species composition of microbial community of water-flooded oil field by chromato-mass spectrometry, Microbiology 63, 490-493.

[23]. Wang, X., Xue, Y., and Xie, S. (1993) Characteristics of enriched cultures and their application to MEOR field tests, Developments in Petroleum Science 39, 335-348.

[24]. Sheehy, A. J. (1991) Development and field evaluation of a new microbial EOR concept, APEA Journal 31, 386-390.

[25]. Groudeva, V. I., Ivanova, I. A., Groudev, S. N., and Uzunov, G. C. (1993) Enhanced oil recovery by stimulating the activity of the indigenous microflora of oil reservoirs, Biohydrometall. Technol. Proc. Int. Biohydrometall. Symp 2, 349-356.

[26]. Jack, T. R. (1991) Microbial enhancement of oil recovery, Current Opinion in Biotechnology 2, 444-449.

[27]. Dostalek, M., Staud, M., and Rosypalova, A. (1957) Effect of micro.ovrddot.organisms on petroleum hydrocarbons, Ceskoslov. mikrobiol.

[28]. Moses, V., Brown, M. J., Burton, C. C., Gralla, D. S., and Cornelius, C. (1993) Microbial hydraulic acid fracturing, Developments in Petroleum Science 39, 207-229.

[29]. Wagner, M. (1991) Proceedings of the 1990 Int. Conf. on Microbial Enhancement of Oil Recovery, Vol. 31, Elsevier, Amsterdam.

[30]. Dienes, M., and Yaranyi, I. (1973) Increase of oil recovery by introducing anaerobic bacteria into the formation Demjen field, Hungary Koolaj as Fodgas 106, 205-208.

[31]. Karakiewicz, J. (1975) Studies on increasing petroleum oil recovery from Carpalthian deposits using bacteria, Nefta 21, 144-149.

[32]. Lazar, I. (1991) MEOR field trials carried out over the world during the past 35 years, Elsevier Science, Amsterdam.

[33]. Lazar, I. (1998) International MEOR applications for marginal wells, Pakistan J. Hydrocarbon Res 10, 11-30. 
[34]. Peng, Y., and Ji, H. (1997) Field of Microbial Enhanced Oil Recovery, Petroleum Industry Press.

[35]. Lu, J., and Li, M. (2006) Status and prospects of microbial enhanced oil recovery, Inner Mongolia Petrochemical 4, 24-25.

[36]. Dou, Q. (2004) Advances in researches and outlook for microbial enhanced oil recovery, Natural Gas Industry 15, 559-563. 